\title{
УДОСКОНАЛЕННЯ ДЕРЖАВНОЇ ПОЛІТИКИ У СФЕРІ МІСЦЕВОГО САМОВРЯДУВАННЯ В УКРАЇНІ
}

\author{
Дерун Т. М., Мазур В. Г.
}

\section{ВСТУП}

На сучасному етапі розбудови України як демократичної, соціальної та правової держави з урахуванням глобальних змін, які відбулись останнім часом, розвиток місцевого самоврядування $\epsilon$ одним iз пріоритетних напрямів державної політики, яка є важливою сферою діяльності суспільства та держави. Від ефективності державної політики у сфері місцевого самоврядування залежить успішність держави, благополуччя суспільства та гідне життя кожної людини.

Державна політика у сфері місцевого самоврядування має на меті своєчасно виявляти назрілі проблеми розвитку суспільства, аналізувати ï, установлювати причини виникнення, визначати складність, суперечливість і знаходити шляхи їх вирішення, а також реалізується в законодавчо закріплених повноваженнях органів державної влади у сфері місцевого самоврядування, загальнодержавних і регіональних цільових програмах підтримки місцевого самоврядування.

Розуміючи важливість вирішення проблем реформування та модернізації системи місцевого самоврядування для забезпечення стабільності й розвитку держави загалом, на сучасному етапі розвитку всіх гілок влади постає питання про необхідність удосконалення теорії та практики формування та реалізації державної політики у сфері місцевого самоврядування в контексті сучасного державотворення, зумовленого трансформаціями в політичній системі суспільства, проведенням адміністративно-територіальних, регіональних реформ, упровадженням конструктивного соціального партнерства між центром і територіями. Необхідною є модернізація державної політики як у сфері місцевого самоврядування на законодавчому рівні, так i y формуванні відносин «державна влада - місцеве самоврядування громадянське суспільство».

\section{1. Основні напрями вдосконалення державної політики у сфері місцевого самоврядування}

Державна політика у сфері місцевого самоврядування на сьогодні важливий компонент забезпечення життєдіяльності суспільства й тому 
актуальним i необхідним $є$ вдосконалення процесу формування державної політики у сфері місцевого самоврядування.

Удосконалення державної політики у сфері місцевого самоврядування повинно здійснюватись через удосконалення організації процесу розробки й реалізації політики; обгрунтування пріоритетів і механізмів політики на встановлений період; визначення порядку й організації державної підтримки розвитку місцевого самоврядування; організацію розподілу прибутків і витрат між бюджетами різних рівнів 3 урахуванням мети й завдань політики в порядку, встановленому бюджетним законодавством; визначення порядку й організації інформаційного забезпечення розробки й реалізації політики.

Уважаємо, що у процесі формування та реалізації державної політики у сфері місцевого самоврядування задля ii вдосконалення варто дотримуватись таких принципів:

- Конституційність і законність - дозволяє забезпечити єдність законодавчих і нормативних актів, їх конституційність і законність.

- Централізація і децентралізація - дозволяє забезпечити рішення завдань державної політики у сфері місцевого самоврядування, активізувати всіх учасників іiі реалізації.

- Узгодження загальнодержавних і територіальних інтересів дозволяє реалізувати політику шляхом прийняття програм і проєктів, спрямованих на розвиток територій, не погіршуючи їх соціальноекономічний стан, але покращуючи демографічні показники розвитку території.

- Обгрунтованість інструментарію управління на національному й регіональному рівнях - дозволяє досягти мети ефективного використання ресурсного потенціалу території, тим самим забезпечити рішення завдань політики.

- Доступність і гласність механізмів, які забезпечують реалізацію політики - дозволяс забезпечити доступність розробки й реалізації для проведення оцінки якості реалізації завдань політики.

- Самоорганізація - дозволяє координувати зусилля суспільства для досягнення мети. Головна мета - сформувати зацікавлений підхід учасників розвитку територій щодо створення потужної інфраструктурної бази, що буде стимулом для інвесторів та імпульсом для населення.

- Субсидіарність - дозволяє забезпечити рішення проблем розвитку території шляхом зближення влади й населення в рішенні завдань політики. 
- Адекватність методів - дозволяє вирішити проблеми наявних протиріч між трьома гілками територіальної політики 3 метою недопущення взаємознищення економічної, культурної політики ${ }^{1}$.

Ураховуючи сучасні тенденції розвитку місцевого самоврядування та підходи до формування та реалізації державної політики в Україні, основними напрямами вдосконалення державної політики у сфері місцевого самоврядування визначені такі:

1. Інституційне забезпечення державної політики у сфері місцевого самоврядування. Вивчення актуальних проблем інституційного забезпечення процесів формування та реалізації державної політики взаємодії громадськості та держави в Україні дає можливість визначити такі аспекти його вдосконалення:

1) подальше вдосконалення інституційного забезпечення державної політики взаємодії громадськості та держави в Україні має здійснюватись згідно з ії євроінтеграційним курсом. У цьому контексті особливу увагу варто звернути на Хартію багаторівневого управління в Європі (Charter for Multilevel Governance in Europe), ухвалену Комітетом Регіонів ЄС у 2014 р. 3 метою досягнення економічної, соціальної та територіальної згуртованості в Свропі;

2) еволюція інституційного забезпечення державної політики у сфері місцевого самоврядування в напрямі децентралізації на принципах субсидіарності: завдання центральних органів влади розробка концептуальних засад і нормативно-правової бази політики; зростання ролі органів місцевого самоврядування, приватних структур, громадських організацій, агенцій регіонального розвитку у процесах формування та реалізації державної політики у сфері місцевого самоврядування;

3) чітке законодавче визначення функцій, повноважень i відповідальності кожного інституту, котрий бере участь у розробленні й реалізації державної політики у сфері місцевого самоврядування;

4) державний контроль за конституційністю та законністю рішень органів та посадових осіб місцевого самоврядування, врахування ними загальнодержавних інтересів під час вирішення регіональних чи місцевих питань;

5) імплементація досвіду розвинених країн світу щодо взаємодії держави й місцевих органів влади;

6) активізація участі у процесах формування та реалізації політики наукових установ, неурядових організацій, зокрема агенцій регіонального розвитку, благодійних фондів, суб'єктів підприємництва,

${ }^{1}$ Пухир С. Т. Сучасні підходи у формуванні та реалізації державної політики регіонального розвитку. Регіональна економіка. 2016. № 3. С. 26-33. 
приватних консультантів та експертів, тобто всіх інституційних партнерів, зацікавлених у сприянні регіональному та місцевому розвитку

7) поглиблення взаємодії між суб'єктами підприємництва й органами державної влади та місцевого самоврядування на принципах державно-приватного партнерства;

8) концентрація обмежених ресурсів на тих заходах і територіях, які можуть забезпечити найбільшу віддачу в найбільш стислий час, однак матимуть довготривалий і комплексний ефект на розвиток не лише однієї території, а й сусідніх регіонів ${ }^{3}$.

- Координації діяльності органів влади, що є однією з основних, стрижневих проблем реформування державного управління, котра визначається найбільш актуальною й такою, яка продовжує негативно впливати на якість формування та реалізації державної політики, зокрема й у сфері місцевого самоврядування. На сьогодні фактично $\epsilon$ три центри формування державної політики в різних сферах життя суспільства: Президент України, Верховна Рада України та Кабінет Міністрів України, які не завжди здійснюють свою діяльність узгоджено та скоординовано. Історія української державності свідчить, що відносини між цими центрами іноді характеризуються як конкурентні, а почасти й конфронтаційні. Надзвичайна заполітизованість процесу формування сфер впливу різних гілок державної влади ускладнює вирішення цієї проблеми через унесення змін до Конституції України, які б дозволили оптимізувати повноваження різних органів державної влади та органів місцевого самоврядування щодо формування засад, здійснення дієвої державної політики.

- Взаємодія громадськості та держави. У цьому контексті йдеться про посилення механізмів впливу громадян на владу, прозорість та підзвітність останньої перед громадянами, а також упровадження механізмів публічної політики в бюджетних процесах як найбільш важливих складників вироблення політики на національному, регіональному та місцевому рівнях. На сьогодні в Україні основними формами взаємодії громадськості та держави $є$ участь інститутів громадянського суспільства у виробленні та обговоренні політикоуправлінських рішень, сприяння наданню громадськими організаціями соціальних послуг населенню, проведення органами публічної влади

2 Ткачук А. Ф. Регіональна політика: правове регулювання. Світовий та український досвід. Київ : Леста, 2011. 260 с.

3 Гринчук Ю. С., Коваль Н. В., Вихор М. В. Система інституційного забезпечення формування та реалізації державної регіональної політики в Україні: проблеми та напрями удосконалення. Інвестиції: практика та досвід. 2019. № 7. C. 23-30. 
моніторингу й аналізу громадської думки, державна фінансова підтримка діяльності організацій «третього сектору», здійснення організаціями громадянського суспільства громадського контролю діяльності органів публічної влади, утворення консультативно-дорадчих та експертних органів тощо. Водночас ключовими принципами зазначеної взаємодії є прозорість і публічність, узгодження інтересів, участь, взаємна підтримка сторін, відповідальність, добровільність, незалежність та етичність ${ }^{4}$.

Ключовою проблемою підвищення ефективності взаємодії держави і громадськості є переведення відкритості та прозорості з декларативних принципів у практичну площину. Зокрема, йдеться про необхідність:

- підвищення інформованості населення про діяльність органів публічної влади за допомогою вилучення зі службового користування документів і матеріалів, які призначені для широкого користування, але фактично є закритими;

- детальне та широкомасштабне висвітлення фактів зловживання в органах публічної влади;

- створення довідкових видань, котрі висвітлюють права громадян у сфері взаємодії з органами публічної влади;

- вироблення методології та практики висвітлення діяльності органів публічної влади 3 метою підвищення їх відкритості за допомогою формування доступної для всіх охочих інформації, що дозволить знизити суб' єктивізм прийнятих ними рішень ${ }^{5}$.

Таким чином, для посилення впливу громадян на владу, підвищення рівня її прозорості та публічності доцільно впровадити комплекс таких заходів ${ }^{6}$ :

- ухвалити Закон України «Про публічні консультації», який повинен чітко регламентувати:

1) критерії обов'язковості проведення публічних консультацій та врахування рекомендацій громадськості;

2) адміністративну відповідальність за порушення суб'єктами владних повноважень процедури організації консультацій із громадськістю;

4 Реформа системи державного управління та місцевого самоврядування в Україні: стан, виклики, перспективи здійснення : наук. доп. / авт. кол. ; за заг. ред. В. С. Куйбіди. Київ : НАДУ, 2018. 180 с.

Романенко Є. О. Відкритість та прозорість як структурні рівні транспарентності державного управління та їх комунікативні функції. Теоретичні та прикладні питання державотворення. 2014. Вип. 14. С. 17-31.

6 Реформа системи державного управління та місцевого самоврядування в Україні: стан, виклики, перспективи здійснення : наук. доп. / авт. кол. ; за заг. ред. В. С. Куйбіди. Київ : НАДУ, 2018. 180 с. 
3) порядок інформування про розгляд пропозицій, отриманих за результатами таких консультацій;

- ухвалити Закон України «Про громадський контроль в Україні», який сприятиме підвищенню функціональності реалізації громадського контролю на різних рівнях;

- забезпечити практику обов'язкових публічних консультацій під час підготовки проєктів Державного бюджету України, місцевих бюджетів, а також підготовки проєктів актів, котрі мають важливе суспільне значення;

- внести зміни до Закону України «Про доступ до публічної інформації», що дозволить припинити практику незаконної відмови або обмеження доступу до публічної інформації органами державної влади;

- розробити єдине положення про структурні підрозділи органів влади, відповідальних за зв'язки із громадськістю, забезпечити формування таких відділів у кожному державному органі центральної та місцевої влади, а також розробити типове положення про підготовку відповідних звітів із метою адекватного інформування громадськості про свою діяльність;

- забезпечити систематичне підвищення кваліфікації працівників відділів зв'язків із громадськістю, органів публічного управління;

- посилити громадський контроль щодо обов'язкового залучення та повноцінної участі в робочих групах, консультативно-дорадчих органах представників громадських організацій та неурядових аналітичних центрів;

- удосконалити порядок інформування громадськості про формування громадських рад, а також оперативно та в повному обсязі інформувати про результати розгляду рішень громадськими радами;

- посилити контроль щодо надання фінансової підтримки організаціям «третього сектору» для реалізації спільних 3 органами публічної влади проєктів та програм;

- посилити інформування громадськості щодо виконання заходів органами публічного управління, спрямованих на підвищення публічності і прозорості вироблення політики, реалізації політиковладних ініціатив, реформаторських дій і рішень, шляхом організації круглих столів, презентацій, публікацій у ЗМІ тощо.

Кадрове забезпечення формування та реалізації державної політики. Ефективність формування та реалізації державної політики у сфері місцевого самоврядування не може бути досягнута без професійних, доброчесних та етичних державних службовців. Актуальність проблеми визначення професійних кваліфікацій та сертифікації публічних службовців в Україні пов'язана з необхідністю розв'язання суперечностей між: 
- вимогами суспільства до професіоналізму фахівців, залучених до публічного управління та адміністрування, й недосконалістю державної політики щодо визначення професійних кваліфікацій та сертифікації публічних службовців в Україні;

- потребою забезпечення системи публічної служби України висококваліфікованими фахівцями й недосконалістю методик, за якими здійснюється відбір персоналу на цю службу, професійна атестація службовців;

- потребою розвитку кадрового потенціалу публічного управління й відсутністю професійних стандартів та неефективністю правового, фінансового, соціально-економічного, інформаційного, психологічного механізмів забезпечення принципів публічного управління та демократії, зокрема прозорості, неупередженості, об'єктивності тощо ${ }^{7}$.

У контексті вищевикладеного є нагальна потреба:

1) законодавчого закріплення Національної рамки кваліфікацій окремим законодавчим актом, переліку кваліфікаційних рівнів Національної рамки кваліфікацій та короткого інтегрованого компетентнісного опису, а також однозначної прив'язки рівнів формальної освіти до кваліфікаційних рівнів Національної рамки кваліфікацій;

2) легітимізації Національної системи кваліфікацій, створення уповноважених організацій з оцінювання та визнання/підтвердження кваліфікацій, інформаційного забезпечення системи освіти, реєстру кваліфікацій;

3) визначення органу, вповноваженого на реалізацію державної політики у сфері професійних кваліфікацій, статус і повноваження якого визначатимуться спеціальним законодавством про систему професійних кваліфікацій;

4) визначення органу, вповноваженого на реалізацію державної політики в системі професійних кваліфікацій у сфері публічного управління;

5) унормування змін у кодах видів економічної діяльності в частині визначення в них такого виду економічної діяльності, як «публічне управління та адміністрування»;

6) визначення можливостей реалізації державно-громадського партнерства в управлінні освітою, зокрема розширення повноважень $\mathrm{i}$ відповідальності громадськості щодо забезпечення якості освіти, визначення змісту освіти, управління закладами освіти та системою освіти загалом, зокрема, шляхом визначення в переліку принципів і засад

\footnotetext{
${ }^{7}$ Куйбіда В. С. Формування та реалізація нової регіональної політики в Україні. Ефективність державного управління. 2017. Вип. 1 (50). Ч. 1. С. 13-20.
} 
освітньої політики принципів державно-громадського управління, державно-громадського партнерства, державно-приватного партнерства ${ }^{8}$.

Нормативно-правове забезпечення процесу формування та реалізації державної політики у сфері місцевого самоврядування. У цьому напрямі доцільно:

- на законодавчому рівні врегулювати статус саморегулівних організацій;

- на рівні актів Кабінету Міністрів України: внести зміни до Регламенту Кабінету Міністрів України щодо узгодження політики, стратегічного планування та погодження проєктів актів Кабінету Міністрів України;

- розробити методику підготовки та зразки програмних i стратегічних документів державної політики 9

Важливим елементом реалізації державної політики у сфері місцевого самоврядування $є$ застосування різних форм оцінки, що дозволяє регулювати процес виконання і проходження етапів реалізації програм. Без цього елементу досить сильно знижується ефективність державної політики. Оцінка реалізації державної політики припускає комплексний підхід, котрий систематизує основні показники значущості рівня можливості реалізації програм, які можуть знаходитись на різних етапах ї реалізації. Основною метою оцінки $є$ збір даних і проведення аналізу інформації про кінцеві і проміжні підсумки, а потім використання іiі для модернізації політики й визначення результативності досягнення кінцевої мети.

\section{2. Використання зарубіжного досвіду для вдосконаленні}

\section{державної політики у сфері місцевого самоврядування}

У сучасних умовах посилення глобалізаційних процесів відбувається структурна трансформація владних систем і механізмів, виявляються недоліки традиційної адміністративно-бюрократичної концепції державного управління. Це змушує уряди держав шукати альтернативні форми управлінської діяльності, адаптовані до якісно нового стану світоустрою. У сучасних світових тенденціях державного управління відбувається перехід від концепції державоцентризму до проблем задоволення потреб людини як основного елемента державноуправлінської системи, для якого, власне, й функціонує держава,

8 Реформа системи державного управління та місцевого самоврядування в Україні: стан, виклики, перспективи здійснення : наук. доп. / авт. кол. ; за заг. ред. В. С. Куйбіди. Київ : НАДУ, 2018. 180 с.

${ }^{9}$ Гринчук Ю. С., Коваль Н. В. Нормативно-правове забезпечення формування та реалізації державної регіональної політики. Інвестииії: практика та досвід. 2019. № 5. C. 9-15. 
реалізується державна політика, функціонують органи державної влади та місцевого самоврядування, проводяться реформи ${ }^{10}$.

Процес реформування державного управління можна уявити як перехід від традиційних цінностей до нових - гнучких та ефективних систем управління, здатних легко адаптуватись до зовнішнього середовища, котре швидко змінюється.

Очевидно, що ефективність державного управління значною мірою залежить від діяльності керівників вищої ланки, недооцінка роботи яких завжди призводила до негативних наслідків. Трансформаційні процеси в сучасному суспільстві створюють умови до появи зовсім іншого типу державного службовця, найбільш важливими рисами якого мають бути вміння оперативно приймати рішення; гнучко адаптуватись до мінливих ситуацій і виробничих технологій; креативність; здатність до інновацій. Визнання особливої ролі керівної ланки в держапараті сприяло появі в розвинених країнах світу окремого інституту - служби вищих чиновників, котра дозволяє відбирати найбільш талановитих $\mathrm{i}$ компетентних фахівців, зорієнтованих не на власну кар'єру, а на сумлінне виконання своїх службових обов' язків ${ }^{11}$.

Із цією ж метою вводяться стандарти професійної компетенції вищих чиновників у сфері менеджменту, від яких у сучасних умовах вимагається не тільки знання, але й нові якості державних лідерів. Ідеться про їхню здатність визначати стратегічні завдання і пріоритети, розуміти політичний контекст та інституційні чинники, що зумовлюють певну ситуацію; враховувати позицію та інтереси різних груп і змінювати баланс сил у потрібному напрямі; оцінювати етичні аспекти й соціальні наслідки рішень; забезпечувати дотримання демократичних норм i цінностей, управляти політичними й організаційними змінами 3 урахуванням культурних, національних, інституціональних чинників ${ }^{12}$.

Для України такий досвід є надзвичайно корисним, адже останнім часом підвищення заробітної плати мотивується/здійснюється не на основі зіставлення обсягу, результативності та якості праці державних

${ }^{10}$ Барановський Ф. В. Вплив громадського суспільства на процес європейської та євроатлантичної інтеграції: український контекст. Наукові записки Інституту політичних і етнонаціональних досліджень ім. І. Ф. Кураса НАН Украӥни. 2017. Вип. 3. С. 198-218.

${ }^{11}$ Красівський О. Я., Киричук О. С. Розвиток системи управління в ЄС: досвід для України : наукова розробка / за заг. ред. О. Я. Красівського. Київ : НАДУ, 2013. $56 \mathrm{c}$.

12 Зарубіжний досвід державного управління: доцільність і можливості застосування в Україні : наукова розробка / І. А. Грицяк, Л. А. Шереметьєва, К. К. Баранцева та ін. Київ : НАДУ, 2012. 56 с. 
службовців, а здебільшого боротьбою $з$ корупцією: велика заробітна плата застереже від хабарництва та корупції.

Варто підкреслити, що основними напрямами державноуправлінських реформ у країнах Європейського Союзу на сучасному етапі є:

- інформатизація та дебюрократизація - означають перехід від концепції класичної бюрократії, яка спирається на ієрархічність i закритість системи управління, до нової інформаційної парадигми, заснованої на відкритих мережевих структурах та управлінні за результатами;

- новий менеджеризм - передбачає залучення передових розробок та основних принципів управління 3 бізнес-менеджменту, що передбачає сучасне уявлення про організацію як гнучку «балансуючу» систему, здатну адаптуватись до викликів зовнішнього середовища ${ }^{13}$;

- децентралізація (деконцентрація, аутсорсинг) - полягає в тому, щоб спустити процес прийняття рішень на низові рівні - туди, де виникають проблеми. Загалом, функціональна децентралізація спрямована на створення спеціальних напівавтономних державних агентств, які беруть на себе більшу частину сервісних функцій і діють на основі угод із центральними відомствами;

- приватизація та введення економічних елементів регулювання управлінських процесів - може відбуватись у формі продажу організацій держсектору або передачі державою своїх служб приватному сектору через систему контрактів. Приватизація передбачає також корпоративізацію, коли напівдержавні структури функціонують згідно з ринковими нормами;

- сервісне адміністрування - це ідея адміністрації як служби сервісу, це нове розуміння державних органів як структур, котрі надають послуги громадянам;

- корпоративізм і неокорпоративізм - передбачають створення децентралізованих державних структур нового типу, перехід від класичної бюрократії до корпоративних методів управління ${ }^{14}$.

Суттєвим завданням реалізації реформ у зарубіжних країнах $\epsilon$ розробка системи регламентів роботи державних органів iз

13 Єгіозар'ян А. Г. Реалізація принципів нового публічного менеджменту та належного врядування в сучасних західних моделях державного. Державне управління та місиеве самоврядування. 2015. Вип. 4. С. 23-31. URL : http://nbuv.gov.ua/ UJRN/dums_2015_4_5.

14 Єгіозар'ян А. Г. Реалізація принципів нового публічного менеджменту та належного врядування в сучасних західних моделях державного. Державне управління та місиеве самоврядування. 2015. Вип. 4. С. 23-31. URL : http://nbuv.gov.ua/ UJRN/dums_2015_4_5 (дата звернення: 07.05.2020). 
громадянами. Наприклад, у Великобританії запроваджена система стандартів роботи із громадянами, яка передбачає визначення для державних службовців показників роботи з населенням. У Франції, відповідно до закону про регулювання державної служби, для кожної державної установи встановлені певні зобов'язання перед громадянами. Крім того, уряд цієї країни запровадив процедуру спрощення отримання багатьох видів послуг, увів нові правила прийому платежів у населення ${ }^{15}$.

Важливим складником реформ у багатьох країнах сьогодні $\epsilon$ створення спеціальних служб із надання державних послуг населенню. Наприклад, із метою допомоги під час працевлаштування кожному громадянину виділяється індивідуальний кейс-менеджер (casemanager), який виконує за клієнта всі процедури, пов'язані 3 отриманням необхідних довідок від відповідних державних служб, а також дає необхідні клієнту рекомендації щодо всього циклу надання послуги ${ }^{16}$.

Необхідно виділити також такий напрям реформ європейських країн, як підвищення прозорості й оперативності надання послуг громадянам. Із метою підвищення прозорості та якості системи послуг, котрі надаються, державні департаменти щорічно розробляють та подають на своїх офіційних сайтах звіти за індикаторами кодексу кращої практики.

Особливу увагу уряди країн Європейського Союзу відводять проблемі підвищення ефективності та якості діяльності державних органів влади, які надають послуги населенню. Наприклад, основна мета адміністративної реформи в Німеччині полягає у створенні «нової моделі адміністрації як служби гарантованого сервісу». Суть такого підходу полягає в тому, щоб передоручати надання вартісних послуг приватним фірмам, забезпечуючи 3 боку уряду тільки гарантію належного виконання наданих послуг. Водночас акцент робиться на зростанні громадянської активності населення та забезпеченні прав споживачів ${ }^{17}$.

Ураховуючи позитивний досвід реформ державного управління в зарубіжних країнах, євроінтеграційні прагнення нашої держави,

15 Куйбіда В. С., Федулова Л. І. Нова регіональна політика СС: уроки для України : аналітична записка. Київ : НАДУ, 2019. 24 с.

16 Попок А. А. Сучасні підходи до здійснення реформування державного управління: досвід зарубіжних країн. Вісник Національної академії державного управління. URL: http://visnyk.academy.gov.ua/wp-content/uploads/2013/11/2012-2-4.pdf.

17 Качний О. С. Зарубіжний досвід формування механізмів державного управління соціально-економічним розвитком регіонів. Публічне управління та митне адміністрування. 2017. № 2. С. 170-174. 
перспективними напрямами вдосконалення державного управління та формування державної політики в Україні мають бути: формування гнучкої, стабільної та ефективної системи державного управління; професіоналізація державної служби; впровадження принципів децентралізації системи державного управління, сервісного адміністрування, корпоративізму й неокорпоративізму, менеджеризму, що сприятиме підвищенню продуктивності роботи державних установ, наближенню держави до громадян.

Важливими чинниками підвищення ефективності, результативності державної політики $є$ : розвиток партнерства із приватним сектором та багатоаспектної взаємодії із громадськістю; прозорість і відкритість діяльності організацій та установ державного сектору; вдосконалення механізмів звітування, моніторингу й контролю.

Вивчення досвіду зарубіжних країн щодо проведення державноуправлінських реформ, які, зокрема, визначають підходи до формування й реалізації державної політики, зокрема й у сфері місцевого самоврядування, дозволяє виділити основні надбання провідних країн, котрі доцільно використати для вдосконалення державної політики у сфері місцевого самоврядування, а саме:

- перебудова системи відносин виконавчих органів влади 3 іншими державними інститутами влади й управління як по горизонталі, так і по вертикалі (конституційно-політична сфера) (досвід європейських країн щодо побудови системи управління, заснованої на відкритих мережевих структурах та управлінні за результатами, який може бути використаний в Україні під час реалізації державних цільових програм);

- створення організаційних структур, механізмів координації й контролю, включно із центральною адміністрацією, регіональне та місцеве управління та залучення недержавних організацій (організаційна сфера) (досвід Німеччини щодо передання права надавати певні послуги приватним організаціям, забезпечуючи з боку державних органів гарантію належного виконання наданих послуг - у процесі реалізації проєктів у межах державно-приватного партнерства в Україні);

- удосконалення систем та методів управління, адміністративні процедури і процеси (функціональна сфера) (досвід європейських країн щодо звітування державних органів на своїх офіційних сайтах за певною системою індикаторів - під час реалізації продуктів державної політики у сфері місцевого самоврядування в Україні (програм, проєктів));

- формування кадрової політики й державної служби (кадрова сфера) (досвід Франції, де, відповідно до закону про регулювання 
державної служби, наявні зобов'язання органу державної влади перед громадянами);

- управління державними фінансами та виконання бюджету відомствами (фінансово-економічна сфера) (досвід Великобританії у впровадженні концепцій щодо ефективного використання бюджетних коштів та систематичного підвищення якості надання суспільних послуг - під час фінансового забезпечення заходів і програм у межах державної політики у сфері місцевого самоврядування).

Таким чином, невід'ємним складником розвитку України в умовах децентралізаційних реформ $є$ вдосконалення процесу формування та реалізації державної політики у сфері місцевого самоврядування на основі врахування надбань, досвіду зарубіжних країн щодо створення та функціонування ефективної системи державного управління, головними завданнями якої $\epsilon$ запровадження нової ідеології функціонування виконавчої влади й місцевого самоврядування, забезпечення прав і свобод громадян, надання якісних державних та громадських послуг.

\section{3. Співпраця з Радою Свропи під час удосконалення державної політики у сфері місцевого самоврядування}

У контексті нашого дослідження корисним буде вивчення досвіду роботи Ради Свропи щодо функціонування органів, які відповідають за формування та реалізацію політики співдружності, особливо щодо розвитку територій, їх структур та повноважень.

Головними статутними органами Ради Європи є Комітет міністрів та Парламентська асамблея. Комітет міністрів $\epsilon$ керівним органом. До нього належать Міністри закордонних справ держав-членів Ради Європи або їні постійні представники. Комітет міністрів визначає напрями діяльності Ради Свропи, розглядає та приймає рішення щодо висловлених Парламентською асамблеєю рекомендацій, пропозицій міжурядових комітетів та конференцій галузевих міністрів.

Парламентська асамблея Ради Європи (ПАРЄ) виконує дорадчі функції та відіграє важливу роль у визначенні напрямів діяльності Ради Свропи. Під час засідань Асамблеї предметом обговорень можуть бути питання, котрі визначають вплив на життя всієї Європи. Робота парламентарів також відіграє значну роль у визначенні напрямів діяльності Комітету міністрів. Для опрацювання питань із відповідної тематики в Асамблеї функціонують 10 комітетів ${ }^{18}$.

\footnotetext{
${ }^{18}$ Стандарти європейського врядування : навч. посіб. / І. А. Грицяк, О. Ю. Оржель, С. М. Гладкова та ін. / за заг. ред. І. А. Грицяка. Київ : НАДУ, 2011. 184 с.
} 
Конгрес місцевих $\mathrm{i}$ регіональних влад Ради Європи $\epsilon$ консультативним органом (створено у 1994 р). для сприяння розвитку місцевої демократії у країнах Центральної та Східної Свропи, а також процесу регіоналізації в $Є_{\text {вропі }}{ }^{19}$.

Конгрес місцевих і регіональних влад складається 3 депутатів від країн-членів Р€, які $є$ народними обранцями місцевого й регіонального рівнів або призначеними посадовими особами, безпосередньо підпорядкованими виборчому місцевому чи регіональному органу.

Відповідно до своїх статутних завдань Конгрес: $є$ форумом, на якому представники органів місцевої й регіональної влади можуть обговорювати спільні проблеми, обмінюватись досвідом і представляти урядам свій погляд щодо цього (у вигляді резолюції); консультує Комітет міністрів та Парламентську асамблею з усіх питань, котрі пов'язані 3 місцевою та регіональною політикою (у вигляді рекомендацій); відслідковує стан місцевої й регіональної демократії у країнах-членах Ради Свропи та державах, які є кандидатами на вступ до Ради Європи, а також здійснює моніторинг дотримання положень Свропейської хартії місцевого самоврядування (у вигляді висновків та звітів); здійснює співробітництво з національними та міжнародними організаціями, що представляють органи місцевої й регіональної влади тощо.

Статутними комітетами Конгресу Ради Свропи є:

1. Комітет 3 інституційних питань, який вивчає питання дотримання країнами-членами своїх зобов'язань, відповідає за здійснення моніторингу, а також специфічні питання щодо інфраструктури органів місцевого й регіонального самоврядування;

2. Комітет із питань соціальної рівності, котрий відповідає за питання громадянства, охорони здоров'я, забезпечення зайнятості населення, суспільні відносини тощо;

3. Комітет із питань культури та освіти, до відання якого належать питання свободи слова та ЗМІ, молодіжної політики, культури, освіти, спорту та зв'язку;

4. Комітет із питань сталого розвитку, що займається питаннями охорони довкілля, плануванням розвитку міст.

Однією з найважливіших робочих груп Конгресу є група «Регіони із законодавчими повноваженнями», яка складається 3 вищих представників органів самоврядування регіонів Європи, що мають законодавчі повноваження, та вирішує питання, пов'язані 3

${ }^{19}$ Гринчук Ю. С., Коваль Н. В. Нормативно-правове забезпечення формування та реалізації державної регіональної політики. Інвестиції: практика та досвід. 2019. № 5. C. 9-15. 
визначенням принципів регіонального розвитку, децентралізації та регіоналізації ${ }^{20}$.

Ураховуючи роль Ради Свропи як провідної організації із прав людини, яка забезпечує високі європейські правові стандарти й акумулює кращі практики їх реалізації, Парламентська асамблея здійснює тісне співробітництво України з відповідними органами Ради Європи. Така взаємодія містить підтримку в реалізації у стратегічно важливих областях внутрішніх реформ, зокрема децентралізації, судової системи та виборчого законодавства, боротьби з корупцією та ефективного захисту прав людини.

Рада Європи в різний спосіб бере участь у розвитку ефективного врядування та вироблення політики в Україні. Для розбудови місцевої й регіональної демократії в Україні Рада Європи пропагує кращі європейські практики та стандарти. За участі Ради Європи забезпечується розвиток місцевого самоврядування та централізація. Експертна допомога із правових та інституційних питань також сприяла демократичності процесу формування та реалізації державної політики, зокрема й у сфері місцевого самоврядування. Залучення до співпраці представників національного, регіонального та місцевого рівнів як з урядових структур, так і від громадянського суспільства $\epsilon$ центральним елементом роботи Ради Європи в питаннях демократії та вироблення політики в Україні ${ }^{21}$.

Співпраця Ради Європи під час вироблення політики, зокрема й у сфері місцевого самоврядування, здійснюється на підставі Планів дій. Плани дій Ради Європи впроваджуються, починаючи із 2005 р. Такі плани приймались на періоди 2005-2007 pp., 2008-2010 pp., 2011-2014 pp., 2015-2017 pp., 2018-2021 pp.

Стратегічними напрямами в межах планів дій визначено такі:

- заходи в галузі прав людини, спрямовані на вирішення певних ключових питань, визначених як пріоритетні контрольними органами P€ і рішеннями Європейського суду із прав людини, та на посилення захисту прав людини і краще виконання судових рішень;

- заходи в галузі верховенства права, спрямовані на розвиток демократичних інститутів і процедур на національному, регіональному та місцевому рівнях, а також на сприяння дотриманню верховенства права;

${ }^{20}$ Конгрес місцевих і регіональних влад Ради Європи. Постійне представництво України при Раді Європи. URL: https://coe.mfa.gov.ua/ua/ukraine-coe/congress.

${ }_{21}$ Пухтинський М. О. Трансформація системи місцевого самоврядування в контексті реалізації міжнародно-правових стандартів місцевої демократії. Вісник АПСВТ. 2016. № 3-4. С. 63-67. 
- заходи в галузі демократії, спрямовані на зміцнення демократичних інститутів на національному, регіональному та місцевому рівнях, на поширення культури демократії, на розвиток соціальної єдності, підвищення терпимості та розширення участі ключових соціальних та громадських партнерів у процесі прийняття рішень $^{22,23}$.

Шляхом підтримки впровадження європейських стандартів ефективного управління та вироблення політики Рада Свропи доклала зусиль для посилення інституціональної значущості місцевої влади. За сприяння експертів Ради Свропи було надано експертні висновки щодо реформи місцевого самоврядування, територіальної організації та законів, які базуються на Праві територіальних громад на об'єднання та на Співпраці територіальних громад. У 2014 р. Венеціанська комісія шляхом оцінки проєктів відповідних змін до Конституції підготувала початок реформи децентралізації. Представникам влади України також допомагали в обговоренні ухваленої Конгресом Рекомендації № 348 (2013 р.) щодо місцевої та регіональної демократії в Україні.

Рада Свропи та Україна продовжуватимуть співпрацю, щоб забезпечити ефективне впровадження чинної законодавчої бази й посилити спроможність національних інституцій щодо узгодження національних законодавства та практики з європейськими стандартами 3 метою сприяння правам людини, зміцнення верховенства права та забезпечення демократичних принципів урядування.

До міжнародних стандартів належать міжнародно-правові норми, котрі регламентують основні принципи, форми й методи здійснення муніципальної діяльності, прийняті державами світу в межах міжнародних, міждержавних органів та організацій. Ці організації та органи діють на загальносвітовому рівні (Всесвітній Союз органів місцевого самоврядування), в межах інституцій Європейського Союзу (зокрема, Комітет регіонів), Ради Свропи (Парламентська Асамблея, Комітет Міністрів, Свропейська комісія «За демократію через право» Венеціанська комісія, Конгрес місцевих і регіональних влад Ради Європи), а також міжнародних об'єднань органів місцевого й регіонального самоврядування. Вони розробляють та приймають різноманітні документи: хартії, декларації, конвенції, резолюції, рекомендації, які стосуються різних сфер локальної демократії, муніципальної діяльності: транскордонного співробітництва,

${ }^{22}$ Співробітництво з Радою Європи. Урядовий портал. URL: https://www.kmu.gov.ua/ ua/diyalnist/yevropejska-integraciya/spivrobitnictvo-z-radoyu-yevropi.

${ }^{23}$ План дій для України на 2018-2021 pp. URL : https://rm.coe.int/coe-action-planfor-ukraine-2018-2021-ukr/1680925bec. 
застосування принципу субсидіарності, участі вповноважених із прав людини (омбудсманів) на місцевому й регіональному рівнях у захисті прав громадян, фінансових ресурсів органів місцевої влади, участі громадян у місцевому політичному житті, комунальної власності 3 огляду на принципи Європейської Хартії місцевого самоврядування, неурядових організацій у системі місцевої й регіональної демократії, участі громадськості у справах місцевого значення й виборах тощо ${ }^{24}$.

Із метою узгодження процесу реформування місцевого самоврядування в Україні 3 європейськими стандартами та кращими практиками країн-членів Ради Європи залучаються та використовуються можливості Європейського комітету з питань демократії та врядування (складається 3 високопосадовців міністерств, відповідальних за місцевий i регіональний розвиток, 47 країн-членів Ради Європи) та Центру експертизи реформ місцевого самоврядування Ради Європи (акумулює досвід та залучає провідних експертів країн-членів). Проводяться фахові дослідження та заходи за участю керівників профільних міністерств країн-членів Ради Європи, зокрема з питань упровадження реформи, процесів співробітництва та об'єднання територіальних громад, секторальної децентралізації, а також навчально-ознайомчі та ознайомчі візити на заходи Ради Свропи та до ії країн-членів. На запит уряду України у 2016 році Рада Свропи призначила в Україну для роботи на постійній основі Спеціального радника Уряду України з питань децентралізації Даніеля Попеску. У межах постійної експертної підтримки України у сфері розвитку місцевого самоврядування за участі Генерального директорату з питань демократії - II Генерального секретаріату Ради Європи та Центру експертизи реформ місцевого самоврядування та їх програм із 2010 р. підготовлено близько 50 експертиз.

Таким чином, складна та багатовекторна діяльність Ради Європи та iii інституцій, їх довід у проведенні реформ у сфері місцевого самоврядування становить значний інтерес для органів державної влади в Україні та може бути запозичений під час здійснення державно-управлінських дій щодо формуванні державної політики, а саме досвід щодо: взаємодії органів державної влади та місцевого самоврядування на основі рекомендацій або конвенції та угоди щодо визначення участі в них; розбудови місцевої й регіональної демократії та досвід проведення реформ місцевого самоврядування, територіальної організації; принципів, стадій (процесу) та вимог до

24 Толкованов В. В. Стандарти та принципи доброго врядування на місцевому й регіональному рівнях як загальноєвропейська цінність. Державне управління: удосконалення та розвиток. 2012. № 12. URL: http://www.dy.nayka.com.ua/?op=1\&z=565. 
вироблення державної політики; підходу до розробки планів дій, етичних кодексів та процедур для державних службовців та службовців органів місцевого самоврядування; виборів та здійснення виборчого процесу; посилення спроможності національних інституцій щодо узгодження законодавства 3 метою сприяння правам людини, зміцнення верховенства права та забезпечення демократичних принципів урядування; принципів, форм i методів здійснення муніципальної діяльності.

\section{ВИСНОВКИ}

Державна політика у сфері місцевого самоврядування як важливий елемент внутрішньої політики держави має бути динамічною й конструктивною, враховувати місцеві й регіональні особливості, соціально-економічні проблеми. Вона не повинна призвести до багатовладдя, протистояння центральної, регіональної й місцевої влади, тому їі пріоритетами повинно бути:

- удосконалення організації й функціонування системи місцевого самоврядування, формування iii територіальної основи - базових адміністративно-територіальних одиниць, у межах яких громади, жителі цих адміністративно-територіальних одиниць самостійно вирішують усі питання місцевого значення;

- оптимізація організаційних засад здійснення виконавчої влади на регіональному та місцевому рівнях, чіткий розподіл повноважень між органами місцевого самоврядування та місцевими органами державної влади;

- зміцнення гарантій місцевого самоврядування, вдосконалення механізмів захисту прав та інтересів територіальних громад, їх органів, посадових осіб;

- створення умов для взаємодії територіальних громад, зокрема на регіональному та міжнародному рівнях.

Удосконалюючи державну політику у сфері місцевого самоврядування, доцільно використати досвід зарубіжних країн щодо таких аспектів: перебудови системи відносин виконавчих органів влади 3 іншими державними інститутами влади й управління як по горизонталі, так і по вертикалі; створення організаційних структур, механізмів координації й контролю, включно 3 центральною адміністрацією, регіональне та місцеве управління та залучення недержавних організацій; удосконалення систем та методів управління, адміністративних процедур і процесів; формування кадрової політики й державної служби; управління державними фінансами та виконання бюджету відомствами. Співпраця 3 Радою Європи у процесі вироблення державної політики у сфері місцевого самоврядування 
сприятиме подальшій експертно-консультативній підтримці розбудови місцевої й регіональної демократії, проведенню реформ місцевого самоврядування, територіальної організації; посиленню спроможності національних інституцій щодо формування та реалізації якісної державної політики.

\section{АНОТАЦІЯ}

У досліджені розкриваються питання вдосконалення процесу формування та реалізації державної політики у сфері розвитку місцевого самоврядування. Із вираховуванням сучасних тенденцій розвитку місцевого самоврядування та підходів до формування та реалізації державної політики в Україні визначено основні напрями вдосконалення державної політики у сфері місцевого самоврядування та конкретні пропозиції їх упровадження. Вивчено сутність та складники державно-управлінських реформ у країнах Європейського Союзу, які на сьогодні запроваджуються. На основі позитивного досвіду реформ державного управління в зарубіжних країнах та 3 урахуванням євроінтеграційних прагнень України визначено перспективні напрями вдосконалення державної політики у сфері місцевого самоврядування. Досліджено особливості співпраці з Радою Свропи у процесі формування, реалізації та вдосконалення державної політики у сфері місцевого самоврядування України.

\section{ЛІТЕРАТУРА}

1. Пухир С. Т. Сучасні підходи у формуванні та реалізації державної політики регіонального розвитку. Регіональна економіка. 2016. № 3. C. 26-33.

2. Ткачук А. Ф. Регіональна політика: правове регулювання. Світовий та український досвід. Київ : Леста, 2011.260 с.

3. Гринчук Ю. С., Коваль Н. В., Вихор М. В. Система інституційного забезпечення формування та реалізації державної регіональної політики в Україні: проблеми та напрями удосконалення. Інвестииї: практика та досвід. 2019. № 7. С. 23-30.

4. Реформа системи державного управління та місцевого самоврядування в Україні: стан, виклики, перспективи здійснення : наук. доп. / авт. кол. ; за заг. ред. В. С. Куйбіди. Київ : НАДУ, 2018. $180 \mathrm{c}$.

5. Романенко С. О. Відкритість та прозорість як структурні рівні транспарентності державного управління та їх комунікативні функції. Теоретичні та прикладні питання державотворення. 2014. Вип. 14. C. 17-31. 
6. Куйбіда В. С. Формування та реалізація нової регіональної політики в Україні. Ефективність державного управління. 2017. Вип. 1(50). Ч. 1. С. 13-20.

7. Гринчук Ю. С., Коваль Н. В. Нормативно-правове забезпечення формування та реалізації державної регіональної політики. Інвестищії: практика та досвід. 2019. № 5. С. 9-15.

8. Барановський Ф. В. Вплив громадського суспільства на процес європейської та євроатлантичної інтеграції: український контекст. Наукові записки Інституту політичних і етнонаціональних досліджень ім. І. Ф. Кураса НАН України. 2017. Вип. 3. С. 198-218.

9. Красівський О. Я., Киричук О. С. Розвиток системи управління в ЄС: досвід для України : наукова розробка / за заг. ред. О. Я. Красівського. Київ : НАДУ, 2013. 56 с.

10.Зарубіжний досвід державного управління: доцільність i можливості застосування в Україні : наукова розробка / I. А. Грицяк, Л. А. Шереметьєва, К. К. Баранцева та ін. Київ : НАДУ, 2012. 56 с.

11. Сгіозар'ян А. Г. Реалізація принципів нового публічного менеджменту та належного врядування в сучасних західних моделях державного. Державне управління та місиеве самоврядування. 2015. Вип. 4. С. 23-31. URL: http://nbuv.gov.ua/UJRN/dums_2015_4_5 (дата звернення: 07.05.2020).

12. Куйбіда В. С., Федулова Л. І. Нова регіональна політика СС: уроки для України : аналітична записка. Київ : НАДУ, 2019. 24 с.

13. Попок А. А. Сучасні підходи до здійснення реформування державного управління: досвід зарубіжних країн. Вісник Національної академії державного управління. URL: http://visnyk.academy.gov.ua/wpcontent/uploads/2013/11/2012-2-4.pdf (дата звернення: 01.05.2020).

14. Качний О. С. Зарубіжний досвід формування механізмів державного управління соціально-економічним розвитком регіонів. Публічне управління та митне адміністрування. 2017. № 2. С. 170-174.

15. Стандарти європейського врядування : навч. посіб. / І. А. Грицяк, О. Ю. Оржель, С. М. Гладкова та ін. / за заг. ред. І. А. Грицяка. Київ : НАДУ, 2011. $184 \mathrm{c}$.

16. Конгрес місцевих і регіональних влад Ради Свропи. Постійне представництво України при Раді Європи. URL: https://coe.mfa.gov.ua/ ua/ukraine-coe/congress (дата звернення: 28.04.2020).

17. Пухтинський М. О. Трансформація системи місцевого самоврядування в контексті реалізації міжнародно-правових стандартів місцевої демократії. Вісник АПСВТ. 2016. № 3-4. С. 63-67.

18. Співробітництво 3 Радою Європи. Урядовий портал. URL: https://www.kmu.gov.ua/ua/diyalnist/yevropejskaintegraciya/spivrobitnictvo-z-radoyu-yevropi (дата звернення: 01.05.2020). 
19. План дій для України на 2018-2021 pp. URL: https://rm.coe.int/ coe-action-plan-for-ukraine-2018-2021-ukr/1680925bec (дата звернення: 30.04.2020)

20. Толкованов В. В. Стандарти та принципи доброго врядування на місцевому і регіональному рівнях як загальноєвропейська цінність. Державне управління: удосконалення та розвиток. 2012. № 12. URL: http://www.dy.nayka.com.ua/?op=1\&z=565 (дата звернення: 28.04.2020).

\section{Information about authors: Derun T. M.,} Ph.D. in Public Administration, Associate Professor, Associate Professor of the Department of Regional Governance, Local Self-Government and Urban Management of the National Academy for Public Administration under the President of Ukraine 20, Antona Tsedika Str., Kyiv, 03057, Ukraine ORCID iD: 0000-0001-9089-2206

Mazur V. H., Lecturer of the Vinnytsia Educational and Scientific Institute of Economics of the Ternopil National Economic University 11, Lvivska Str., Vinnytsia, 46009, Ukraine ORCID iD: 0000-0002-8133-7355 